\title{
TRIBUTE
}

\section{REFLECTING ON BIRTWISTLE AT 80}

Harrison Birtwistle has been everywhere these past few weeks. On the radio, in magazines and newspapers, and as the focus of the extended Birtwistle at 80 celebrations, which took place during May at the Barbican Centre. Three outstanding CDs have been released, alongside an utterly engaging book of conversations. And there's still more to come: no fewer than seven works at the BBC Proms; the premiere in October in Munich by Pierre-Laurent Aimard of a new piano concerto with the intriguing title Responses (Sweet disorder and the carefully careless); and a three-day mini-festival of his music at the South Bank in early December.

All this is as it should be for a composer of Birtwistle's stature. But such anniversary programming is only so much lazy marketing on the part of publishers and concert promoters if it does not also offer the opportunity for re-evaluation, as well as the chance to draw in new audiences. If the high attendance at and enthusiastic reception of the semi-staged performances at the Barbican of Gawain and Yan Tan Tethera are indicative, then there certainly seems to be a renewed appreciation of Birtwistle's work. Similarly, the thrilling ride that was the LSO and Daniel Harding's performance of Earth Dances on 20 May 2014 was greeted with prolonged cheers, while the reception of the composer onto the platform by a near-full house can only be described as warm and affectionate. Further, the public filled the Barbican's Fountain Room for a study afternoon devoted to Birtwistle's work, culminating in a Q\&A between the composer and Observer music critic Fiona Maddocks. Birtwistle's eightieth birthday, then, has prompted some welcome reflection on the part of programmers and audiences. What does Birtwistle's music mean in the twenty-first century, and why does it matter? How today does one listen differently to the iconic works of earlier decades? How and why does his music continue to speak so powerfully? Many are easily swayed by the ignorant voices of politicians and chattering 'opinion formers' who like to claim that all modernist music is elitist, out-of-touch, accessible only to the privileged few. The growing broad-base audience for Birtwistle's music surely provides evidence to the contrary?

The conversations between Birtwistle and Maddocks, newly published by Faber and Faber under the title Wild Tracks: A Conversation Diary, is the first writing of its kind about the composer. Compiled from some six months of encounters between subject and interviewer, mainly at the kitchen table of his Wiltshire home, it is a gentle and lovingly crafted journey across the familiar themes and obsessions of his life and work: time, memory and melancholy; music, painting and theatre; nature and landscape; family and cooking. While as a matter of principle one should always distrust anything any composer says about his or her own music, in this case there is no reason to assume that Birtwistle's responses are anything other than genuine. There are no shattering revelations; rather, the conversations throw welcome fresh light onto the music. Running like a thread through the weave of the text is Birtwistle's work on the piano concerto, a rare insight into a composer's daily routine. Most striking is his 'neurosis', as he describes it. Composition for him, despite his prodigious prolificness, is never easy: it is, in fact, a constant struggle for him. 'I never felt that anything came naturally. I was always struggling, in ways that perhaps no one really saw, to get where I wanted to be - though I didn't absolutely know where that place was.' He is scared that his 'life is a total waste of time, a failure'. Birtwistle is a self-confessed melancholic, and whether it is looking back on a 'sort of melancholy' experienced in the Sundays of childhood, or his sense of 'aloneness' in adjusting to a new life after the death of his wife Sheila, it is clear that this dark hue pervades both his world-view and his music. He sees himself as 'very much a loner'. Just like Orpheus, who has continually stalked his work.

While such melancholy has been evident in Birtwistle's music even as far back as his first extant composition, The Oockooing Bird, written he claims when he was about 15 years old, it has come increasingly to the fore in the works of the new millennium. The boldness of 
approach and expression that dominated the music of the 1960s - such as Tragoedia, Verses for Ensembles and Punch and Judy - and which stands at the heart of the overwhelming central act of The Mask of Orpheus (premiered in 1986), has in recent years been tempered by a more static and lyrical music that seems to turn inwards, which - inevitably in later life - dwells on loss, and which is more reflective. Key statements since 2000, such as The Minotaur and The Shadow of Night, amply illustrate this. But, for me, some of the most poignant articulations of this melancholic attitude are to be found in the recent chamber music. Two CD releases capture this beautifully, in performances of intelligence and expressivity. The Moth Requiem (2012) is scored for an unmistakably Birtwistlian combination of 12 female voices, alto flute and three harps, and is here given due weight by members of the Nash Ensemble and the BBC Singers under Nicholas Kok. The text is a combination of a poem on moths by the late Robin Blaser, librettist of the millennial opera The Last Supper, and an incantation of the Latin names of moth species. Blaser's inspiration was the sounds made by a moth trapped inside a piano and striking the strings, and that is Birtwistle's starting point too. The first note one hears is, in fact, an E, a familiar point of reference in so many of his works, and a note that has for him so long been associated with melancholy, perhaps because it carries Phrygian resonances. It certainly suggests here a loss and lamenting in keeping with a requiem, situating the work in an Arcadian landscape of shadows. It would be all too easy to make a link between the music's character and the composer's personal circumstances at the time of writing - both in memoriam Robin Blaser, and when Sheila was very ill - since there is certainly an inherent sadness about the piece, as well as passing, violent moments of raging against the dying of the light. Nonetheless, it is a questionable activity to map biography onto work so directly. These themes are nothing new in Birtwistle's work: memory, loss and lament in a desolate landscape are the defining Birtwistle characteristics. In The Moth Requiem, the chanting of the names takes on a dark, ritualistic character.

The other brand-new release of the year so far, a disc of chamber music on ECM, contains music of subtle expression and sensitivity. In particular, the Bogenstricht cycle (2006-9) for baritone, cello and piano is extraordinarily tender, prompted by the text of Rilke's Liebes-Lied, which lies at its heart, and is dedicated to the composer's dying wife. The bow stroke of the title is the poet's metaphor for love:

... all that touches us, you and me, conjoins us like a stroke of a bow, which draws but one voice from two strings.

The mood of the poem is melancholic - 'something lost in darkness at an unknown quiet place' and this echoes out into the five movements, only two of which are sung. These pieces, whose starting point was a commission for the cellist Adrian Brendel, were a genuinely late discovery for Birtwistle of the expressive potential of string instruments, something he had largely avoided in his output until that date. (They have been followed by a major string quartet and a violin concerto.) The direct sounds of blown and hit instruments, one might say, have often unleashed primitive forces in Birtwistle's music, most notably in the 1996 Proms commission Panic, named after the nature-god Pan; the sound of strings, by contrast, mediated by the stroke of a bow, represents culture, the subjective, the reflective, and seems to signal a still greater focus in recent work on speaking personally. The touching performances on this disk - from Brendel, pianist Till Fellner and singer Roderick Williams - capture the crepuscular mood of the music perfectly. Like Orpheus before him, poised on the threshold between dark and light, Birtwistle views the world with clarity and articulates its losses, both personal and collective, while taking solace in the 'geometry' of what must be one of the most highly crafted and contrapuntal pieces he has ever written. Like Dürer before him, whose figure Melancholy in Melancolia I (1514) is surrounded by the tools of geometry, Birtwistle no doubt thinks along the similar lines to Robert Burton, who wrote in 1621 in The Anatomy of Melancholy, 'Whosoever he is therefore that is overrun with solitariness, or carried away with pleasing melancholy and vain conceits, and for want of employment knows not how to spend his time, or crucified with worldly care, I can prescribe him no better remedy than this of study, to compose himself to the learning of some art or science.'

The third CD release of the year is in fact a re-release on the ever-resourceful NMC label of the original Collins Classics recording of Gawain, itself taken from the 1994 BBC broadcast of the opera's revised and curtailed version. It is a source of some regret that someone could not also release the Barbican performance of the fully restored version (broadcast on BBC Radio 3 on 15 July 2014, the very day of the composer's 
eightieth birthday), though I fully recognise the undoubtedly insurmountable costs of additional rights and a three-CD set. Thankfully, we have at least had the chance to compare the two versions. My vote is cast fairly and squarely in favour of the original. Certainly the reinstatement of the full 40 minutes of the 'Turning of the Seasons' tableau at the end of Act I makes for a long evening, but the gains are inestimable in the opportunity it affords to immerse oneself in this overwhelming ritual, structured and controlled by the music, prompting one to think deeply about the importance of ceremony in collective life, about nature and the seasons, about journeying both physical and spiritual, and many other issues besides. The Gawain performance on 16 May 2014, given by the BBC Symphony Orchestra under Martyn Brabbins with Sir John Tomlinson leading a stellar cast, was unforgettable, thanks to the total commitment to the music of all involved.

I was listening again recently to Birtwistle's little Tango for piano written in 2000 for the eightieth birthday of his late American friend, supporter and photographer, Betty Freeman, played by Nicolas Hodges. (In a memorable public aside, Birtwistle recently asserted that Hodges was to him as Peter Pears was to Benjamin Britten! It is clear, certainly, that the composer has a deep affection for the way in which Hodges brings his music to life.) I love this twominute piece. It is the essence of Birtwistle. Using the basic rhythmic pattern of the habanera, it is, he says, "like seeing a tango behind a gauze', and it shares something of Stravinsky's interpretations of that same dance, as well as Ravel's. Yet in Birtwistle's hands the Southern heat of the model is turned into a Northern European wistfulness. It is like the memory of something experienced long ago, in a far-off place, now fractured, incomplete, in ruins.

I was very taken by the recent exhibition at Tate Britain under the title Ruin Lust. In the exhibition catalogue, Brian Dillon, the curator, reminded me that the taste for ruins is a modern invention, by which he means post-medieval. Dillon challenges the viewer with the example of Turner's representation of classical and medieval ruins framed within a landscape, such as in his Temple of Poseidon and Tintern Abbey. In the twentieth century, when entire cities were laid waste by war, the idea of the ruin took on particular poignancy. Thus, the ruin has become for us today a metaphor for human fragility, a symbol of the crisis of an anxious and fragmented modern world, a reminder of the destructive power of both man and time, and a voicing of nostalgia for a lost wholeness. For me this rings true with so much of Birtwistle's work too. In the case of Tango, the listener is left with the ruins, the memory of a once-whole dance; one yearns nostalgically for something more complete while simultaneously knowing it can never be realised. One looks on melancholically, like Orpheus yearning to be reunited with Eurydice, continually dwelling on her loss, yet knowing she can never be recaptured. Via Birtwistle, Orpheus becomes a late-modern figure, a figure of our own time.

In Tango, Birtwistle takes something very simple and makes us look at it in new ways. This is what great art does. And this is why I would argue - prompted by the celebrations of his eightieth birthday - that Birtwistle's music matters, because it responds to and reflects on what it means to live in the late twentieth and early twenty-first centuries. Birtwistle's music succeeds in putting us, the listeners, in touch both with nature and with unconscious feelings deep within us that lie beyond words.

Wild Tracks: A Conversation Diary with Fiona Maddocks by Harrison Birtwistle and Fiona Maddocks. Faber and Faber, 2014. £22.50

'Chamber Music': Harrison Birtwistle. Three Settings of Lorine Niedecker; Trio; Bogenstricht Meditations on a Poem of Rilke; Nine Settings of Lorine Niedecker. Lisa Batiashvili (vln), Adrian Brendel (vc), Till Fellner (pno), Amy Freston (sop.), Roderick Williams (bar.). ECM New Series 2253

Gawain: Harrison Birtwistle. The Royal Opera Chorus, Orchestra of the Royal Opera House, cond. Elgar Howarth. NMC D200

The Moth Requiem, The Ring Dance of the Nazarene, Three Latin Motets, Carmen Paschale, Lullaby, On the Sheer Threshold of the Night: Harrison Birtwistle. Roderick Williams (bar.), BBC Singers, Nash Ensemble, cond. Nicholas Kok. Signum Classics SIGCD368

Jonathan Cross 